\title{
Adiponectin Effect on Nitric Oxide Secretion by Normal and Endometriotic Human Endometrial Stromal Cells: in vitro Study
}

\author{
Efecto de la Adiponectica sobre la Secreción de Óxido Nítrico por Células Estromales \\ de Endometrio Humano, Normales y con Endometriosis: Estudio in vitro
}

Somayeh Bohlouli*; Mozafar Khazaei*; Arezou Rabzia**; Mohammad Rasool Khazaei ${ }^{* * *}$ \& Ehsan Sadeghi****

BOHLOULI, S.; KHAZAEI, M.; RABZIA, A.; KHAZAEI, M. R. \& SADEGHI, E. Adiponectin effect on nitric oxide secretion by normal and endometriotic human endometrial stromal cells: in vitro study. Int. J. Morphol., 33(1):337-341, 2015.

SUMMARY: Endometriosis is an estrogen-dependent disease in reproductive age women. Adiponectin and Nitric oxide (NO) have an important role in physiologic functions especially in human reproductive system. Levels of NO increased in the endometriosis patients but serum adiponectin levels decreased in woman with endometriosis. The aim of this study was to determine adiponectin effect on nitric oxide secretion by cultured normal and endometriotic human endometrial stromal cells. In this experimental study, normal $(\mathrm{n}=10)$ and endometriotic endometrial biopsies $(n=10)$ were taken in sterile condition. Stromal cells isolated and cultured in in DMEM/ F12 medium and treated with adiponectin concentrations $(0,10,100$, and $200 \mathrm{ng} / \mathrm{ml})$ for 24 and 48 hours. NO assay was done on their supernatants by Greiss method. Data was analyzed by one way ANOVA and $\mathrm{p}<0.05$ was considered significant. There was significant difference between endometriosis groups in NO secretion in all dose of adiponectin and time $(\mathrm{p}<0.05)$. In normal groups there was significant difference in 48 hours $(\mathrm{p}<0.05)$ but no significant change in 24 hours ( $>0.05$ ). Adiponectin effects nitric oxide secretion of cultured human endometriotic stromal cells.

KEY WORDS: Adiponectin; Nitric oxide; Endometriosis; Stromal cell.

\section{INTRODUCTION}

Endometriosis is a chronic inflammatory disease that is defined by the presence of endometrial epithelial glands and stromal cells outside of the uterus. The usual site for this female disorder is the pelvic cavity. Endometriosis is one of the disorders of reproductive age women which wellknown as an estrogen-dependent disease (Giudice \& Kao, 2004; Scarselli et al., 2005). Some of the histopathological study report that changes of stromal cells are more than glands in endometriosis tissue. Usually stromal endometriosis is a common form of small superficial microscopic nodules or plaques in endometriosis peritoneal biopsies (Boyle \& McCluggage, 2009). Nitric oxide (NO) is an important free radical with vital roles in physiological and biological system in body. It is generated from L-arginine and does its biological effects by three isoforms of nitric oxide synthase (NOS) enzyme: endothelial cells (eNOS), neurones (nNOS), and inducible form (iNOS) synthases (Kim et al., 2001). (eNOS) and (iNOS) have been found in human endometrium but the main isoform of NOS is endothelial NOS( eNOS) in endometrial glands and stromal cells in the menstrual cycle specially, the secretory phase.
Female sex hormones (estrogen and progesterone) can influence uterine eNOS expression and regulate endometrial eNOS in menstrual cycle (Taguchi et al., 2000; Khorram et al., 1999). NO concentration change in many of biologic and physiological disorder such as inflammation, diabetes, etc. Levels of $\mathrm{NO}$ were raised in the endometriosis patients. In comparison between healthy and endometriosis women patients iNOS protein concentration in the endometrial tissues of endometriosis' patients was higher than in healthy women but there is no difference in endometrial eNOS protein concentration (Wu et al., 2003). Adiponectin is secreted by adipose cells, mediated its physiological effects on the body through its receptors, AdipoR1 and AdipoR2 (Wang et al., 2008). Adiponectin plays an important role in the reproductive system. Adiponectin receptors were expression in the epithelial and stromal cells of endometrial tissue (Takemura et al., 2006). In humans significant decrease of serum levels of adiponectin are seen in woman with endometriosis (Takemura et al., 2005) and in peritoneal liquid in endometriosis patients (Yi et al., 2010). Possibly a decrease in the circulating level of adiponectin and higher

\footnotetext{
* Kermanshah Branch, Islamic Azad University, Kermanshah, Iran.

** Fertility and Infertility Research Center, Kermanshah University of Medical Sciences, Kermanshah, Iran.

**** Research Center for Environmental Determinants of Health (RCEDH), Kermanshah University of Medical Sciences, Kermanshah, Iran.
} 
levels of NO in women with endometriosis, have been associated to pathophysiology and endometriosis progress. Following our previous studies the aim of this study was to find the effect of adiponectin on nitric oxide levels on human endometrial stromal cells in women with and without endometriosis in vitro condition.

\section{MATERIAL AND METHOD}

Sample collection. In this experimental study, endometrial samples consisted of 10 women with endometriosis (mean age, 28 years) and 10 women without endometriosis (mean age, 31 years) in secretory phase of menstrual cycles. They underwent laparoscopy for diagnosis of endometriosis. None of them took hormonal treatment for 3 months before laparoscopy. The experimental procedures were approved by the Ethics Committee of Kermanshah University of Medical Sciences and Kermanshah Branch of Islamic Azad University. Also all women signed informed consent for use of the sample was obtained from them.

Culture methods. Human endometrial stromal cells isolation and culture. The process of isolation and culture of normal and endometriotic HESCs were described previously our studies (Khazaei et al., 2011; Bohlouli et al., 2013). Biopsy samples collected in an aseptic situation. The tissues were chopped and incubated in DMEM/F-12 (Gibco, Denmark) with type I collagenase (Sigma, Germany) for $60-90 \mathrm{~min}$ at $37^{\circ} \mathrm{C}$. After filtration by 40 and $70 \mathrm{~mm}$ filter mesh (cell strainers BD Falcon, USA). ESCs in the filtrate were collected by ficoll and centrifugation, were cultured in DMEM/F-12 containing 10\% FBS, $100 \mathrm{U} / \mathrm{ml}$ penicillin, 0.1 $\mathrm{mg} / \mathrm{ml}$ streptomycin, and $0.25 \mathrm{mg} / \mathrm{ml}$ amphotericin B and maintained at $37^{\circ} \mathrm{C}$ in a humidified atmosphere of 95\% air and 5\% Co2. After 5-7 days ESCs reached density for used the experiments. The purity of the stromal cell preparations was more than $85 \%$, as judged by positive cellular staining for anti-vimentin. ESCs cells were plated in 24well culture plates. Before adding the adiponectin (high molecular weight, R\&D System Minneapolis, MN USA) for experiment, cells were serum-free media overnight and then treatment in the absence and presence of various Adiponectin concentrations (10, 100, and 200 $\mathrm{ng} / \mathrm{ml}$ ) for 24 and $48 \mathrm{~h}$ (Bohlouli et al.).

Nitric oxide assay. In body $\mathrm{NO}$ is changeable and nitrite and nitrate are the stable form of NO. NO quickly transform to its stable metabolites, nitrite and nitrate $\left(\mathrm{NO}_{2}^{-}, \mathrm{NO}_{3}^{-}\right)$(Guevara et al.
1998). We analyzed and compared nitric oxide concentrations in the normal and endometriotic HESCs supernatants with the Greiss method. The Greiss I )Fluka, UK) Reagent is made up of a $1 \%$ solution of sulfanilamide in $5 \%$ phosphoric acid and $0.1 \%$ naphthylethylenediamine dihycrochloride in distilled water. Normal and endometriotic HESCs supernatants were gathered the end of each time and dose of experiment and store at $-20{ }^{\circ} \mathrm{C}$. The protein and phenol red of the supernatant were deleted using Zinc sulfate (6 mg/400 mliter) (Ghasemi et al., 2007). Sodium nitrite $(0.1 \mathrm{M})$ was used for the standard curve, and increasing concentrations of sodium nitrite $(6.25,12.5,25,50,100$, and $200 \mu \mathrm{M}$ ) were prepared. The Greiss solution was added to all micro plates containing sodium nitrite and supernatant and was read by an ELISA reader (stat fax100. USA) in 540 $\mathrm{nm}$ and $630 \mathrm{~nm}$ filters (Bohlouli et al.; Tsikas, 2007).

Statistics. Statistical analysis was performed by one way analysis of variance (ANOVA) and post hoc tukey test. $\mathrm{P}<0.05$ was considered statistically significant.

\section{RESULTS}

In this study secretion of NO in normal and endometriotic human endometrial stromal cells in various concentrations of adiponectin $(0,10,100,200 \mathrm{ng} / \mathrm{ml})$ for 24 and 48 hours was demonstrated by Greiss method. In all adiponectin concentrations, 24 hour in normal human endometrial stromal cells There was no significant difference in NO secretion between the control and case groups ( $p>0.05)$, but for 48 hour there was significant $(\mathrm{p}<0.05)$ (Fig. 1). In endometriotic groups there was significant difference in NO secretion between the control and case groups. All

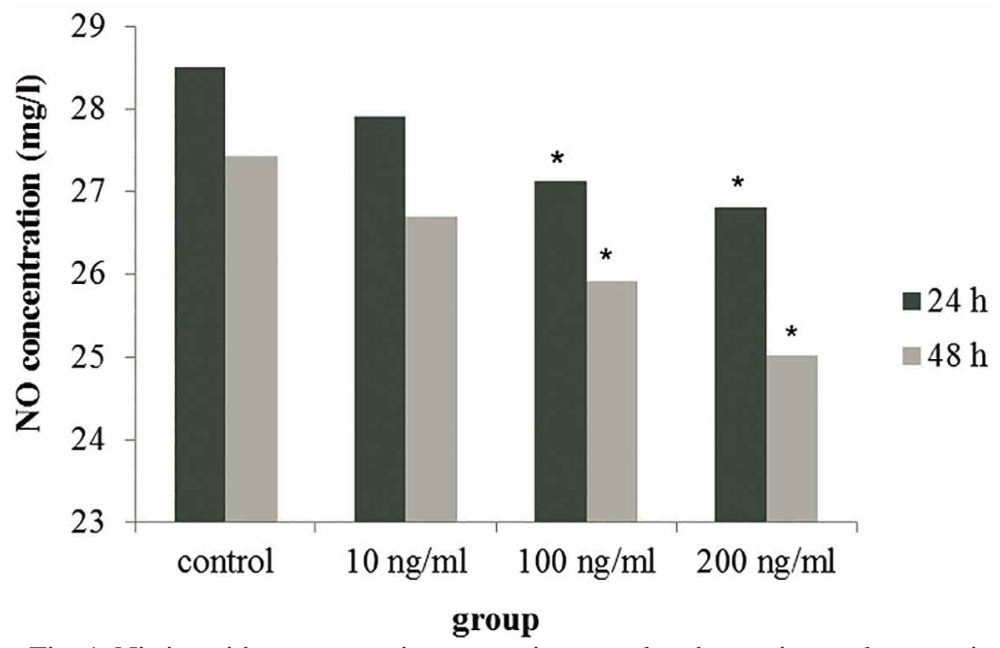

Fig. 1. Nitric oxide concentration means in control and experimental groups in Normal HESCs. *= Significant difference compared to control and experimental groups $(\mathrm{p}<0.05)$. 
concentrations of adiponectin induced decrease NO secretion in 24 and 48 hours in endometriotic HESCs in vitro. There was significant difference between the control and case groups $(\mathrm{p}<0.05)$ (Fig. 2).

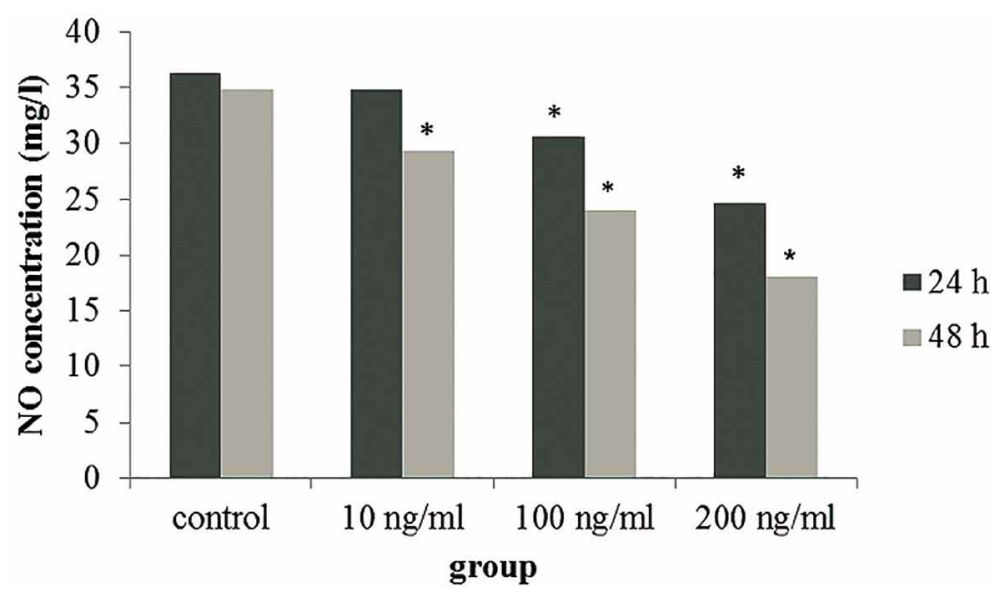

Fig. 2. Nitric oxide concentration means in control and experimental groups in endometriotic HESCs. *= Significant difference compared to control and experimental groups $(\mathrm{p}<0.05)$.

\section{DISCUSSION}

For first time in this study, adiponectin effect on secretion of NO in normal and endometriotic HESCs was survey in the culture. Findings of the study showed that adiponectin depending on dose and time decreased the secretion of NO of endometriotic HESCs significantly in the culture (in vitro). In our previously studies adiponectin effect on viability in normal and endometriotic human endometrial stromal cells in the culture condition was studied and anti-proliferative effect and decrease the viability of endometrial stromal cells have been reported (Bohlouli et al.). The role of adiponectin on inhibitory cell proliferation was confirmed in the cell culture. Adiponectin caused decrease of the viability and their numbers of endometrial carcinoma cell lines (HEC-1A and RL95-2) (Cong et al., 2007) and primary trophoblast cells and trophoblast cell lines (JEG-3 and BEWO) in the culture (Benaitreau et al., 2010). Reduction of level adiponectin in body is an important agent in reproduction illness and infertility. Many factors and mechanisms influence reproduction (these) disorders directly or indirectly (Moon et al., 2011). Endometriosis is one of the important reproductive disorders which caused infertility in women. Decrease of adiponectin concentrations in endometriosis women has been reported (Takemura et al., 2005; Yi et al.). Previous studies reported (NOS) isoforms (eNOS and iNOS) exist in human endometrium in the menstrual cycle and nitric oxide levels intensify in the late proliferative and secretory phase of menstrual cycle (Taguchi et al.; Khorram et al.; Giulini et al., 2012). Also (iNOS) increases in the uterus during embryo implantation (Saxena et al., 2000). NO concentration increased in the endometrial tissues of endometriosis patient women specially, (iNOS) protein concentration ( $\mathrm{Wu}$ et al.). Expression of (iNOS) in human endometrial stromal cell was investigated in cell culture. Maybe (iNOS) act in the control of endometrial functions (Yoshiki et al., 1999). Estrogen and progesterone can regulate the expression of nitric oxide synthase isoforms in the human endometrium especially human endometrial stromal cells (Khorram et al.; Han et al., 2005). Actions of nitric oxide were survey on human endometrial cell in vitro. These studies pointed out that NO have a different function on endometrial cell in the cultured. Presumably No caused proliferation on the endometrial stromal cell and apoptosis on the epithelial cell in the cultured (Johnson et al., 2005). Based on the previous studies results, adiponectin concentrations decrease in endometriosis (Takemura et al., 2005; Yi et al.) and NO concentrations increase in endometriosis patient (Wu et al.). Also based on our previous findings adiponectin by its receptors mRNA expression (AdipoR1 and AdipoR2) influence endometrial stromal cells in the culture and caused decrease in the proliferation and viable cell number of normal and endometriotic HESCs in vitro condition and prevent endometriosis progresses (Bohlouli et al.). So it is possible adiponectin effect on expression of NO synthase isoforms in endometrium especially stromal cells and decrease NO level in stromal cells cultured and improves inhibition of endometriosis progresses.

\section{CONCLUSION}

The findings in our studies commented in future effect of adiponectin on expression Nitric oxide isoforms synthase (eNOS and iNOS) in human endometrial stromal cells must be investigated.

\section{ACKNOWLEDGEMENTS}

This research financially supported by Kermanshah Branch, Islamic Azad University, Kermanshah, Iran as project no. 44-3. There is no conflict of interest in this study. 
BOHLOULI, S.; KHAZAEI, M.; RABZIA, A.; KHAZAEI, M. R. \& SADEGHI, E. Efecto de la adiponectica sobre la secreción de óxido nítrico por células estromales de endometrio humano, normales y con endometriosis: estudio in vitro. Int. J. Morphol., 33(1):337$341,2015$.

RESUMEN: La endometriosis es una enfermedad dependiente de estrógenos que se presenta en mujeres en edad reproductiva. La adiponectina y el óxido nítrico $(\mathrm{ON})$ tienen un papel importante en las funciones fisiológicas, especialmente en el sistema reproductivo humano. Los niveles de ON aumentan en los pacientes con endometriosis, pero los niveles de adiponectina en suero disminuyen. El objetivo fue determinar el efecto de la adiponectina sobre la secreción de ON por las células estromales de endometrio humano, tanto normales como con endometriosis, en medio de cultivo. En este estudio experimental, las células estromales de endometrio normales ( $\mathrm{n}=$ 10) y las biopsias de endometrio con endometriosis $(\mathrm{n}=10)$ se tomaron en condiciones de esterilidad. Las células estromales fueron aisladas y cultivadas en un medio DMEM/F12, y se sometieron a distintas concentraciones de adiponectina (0, 10, 100, y 200 ng/ml) durante 24 y 48 horas. El ensayo con ON se realizó a los sobrenadantes obtenidos por el método de Greiss. Los datos recolectados fueron analizados por ANOVA de una vía y un valor p<0,05 se consideró significativo. Entre los grupos con endometriosis, en referencia a la secreción de ON, no hubo diferencia significativa en todas las dosis de adiponectina y los tiempos estipulados ( $<<0,05)$. En los grupos normales, hubo diferencia significativa a las 48 horas ( $\mathrm{p}<0,05)$, pero ningún cambio significativo a las 24 horas $(\mathrm{p}>0,05)$. La adiponectina tiene efectos sobre la secreción de óxido nítrico por las células estromales endometriales humanas en cultivo.

PALABRAS CLAVE: Adiponectina; Óxido nítrico; Endometriosis; Células estromales.

\section{REFERENCES}

Benaitreau, D.; Dos Santos, E.; Leneveu, M. C.; De Mazancourt, P.; Pecquery, R. \& Dieudonné, M. N. Adiponectin promotes syncytialisation of BeWo cell line and primary trophoblast cells. Reprod. Biol. Endocrinol., 8:128, 2010.

Bohlouli, S.; Khazaei, M.; Teshfam, M. \& Hassanpour, H. Adiponectin effect on the viability of human endometrial stromal cells and mRNA expression of adiponectin receptors. Int. J. Fertil. Steril., 7(1):43-8, 2013.

Boyle, D. P \& McCluggage, W. G. Peritoneal stromal endometriosis: a detailed morphological analysis of a large series of cases of a common and under-recognised form of endometriosis. J. Clin. Pathol., 62(6):530-3, 2009.

Cong, L.; Gasser, J.; Zhao, J.; Yang, B.; Li, F. \& Zhao, A. Z. Human adiponectin inhibits cell growth and induces apoptosis in human endometrial carcinoma cells, HEC-1-A and RL95 2. Endocr. Relat. Cancer, 14(3):713-20, 2007.

Ghasemi, A.; Hedayati, M. \& Biabani, H. Protein Precipitation Methods Evaluated for Determination of Serum Nitric Oxide End Products by the Griess Assay. J. Med. Sci. Res., 2:29-32, 2007.

Giudice, L. C. \& Kao, L. C. Endometriosis. Lancet, 364(9447):178999, 2004.

Giulini, S.; Carbone, M. M.; La Marca, A.; Tirelli, A.; Radi, D. \& Volpe, A. Nitric Oxide concentration in endometrial washing throughout the menstrual cycle. Arch. Gynecol. Obstet., 285(5):1479-82, 2012.

Guevara, I.; Iwanejko, J.; Dembin'ska-Kiec', A.; Pankiewicz, J.; Wanat, A.; Anna, P.; Go?abek, I.; Bartus’, S.; Malczewska-Malec,
M. \& Szczudlik, A. Determination of nitrite/nitrate in human biological material by the simple Griess reaction. Clin. Chim. Acta, 274(2):177-88, 1998.

Han, G.; Magee, T. \& Khorram, O. Regulation of nitric oxide synthase isoforms by estrogen in the human endometrium. Fertil. Steril., 84(Suppl. 2):1220-7, 2005.

Johnson, M. C.; Maliqueo, M.; Boric, M. A.; Villavicencio, A.; Vantman D. \& Vega, M. Differential in vitro actions of nitric oxide on human endometrial cell survival. Fertil. Steril., 81(1):176-84, 2004.

Khazaei, M.; Roshankhah, S.; Ghorbani, R. \& Chobsaz, F. Sildenafil Effect on Nitric Oxide Secretion by Normal Human Endometrial Epithelial Cells Cultured In vitro. Int. J. Fertil. Steril., 5(3):1427, 2011.

Khorram, O.; Garthwaite, M. \& Magness, R. R. Endometrial and myometrial expression of nitric oxide synthase isoforms in preand postmenopausal women. J. Clin. Endocrinol. Metab., 84(6):2226-32, 1999.

Kim, P. K.; Zamora, R.; Petrosko, P. \& Billiar, T. R. The regulatory role of nitric oxide in apoptosis. Int. Immunopharmacol., 1(8):1421-41, 2001.

Moon, H. S.; Chamberland, J. P.; Aronis, K.; Tseleni-Balafouta, S. \& Mantzoros, C. S. Direct role of adiponectin and adiponectin receptors in endometrial cancer: in vitro and ex vivo studies in humans. Mol. Cancer Ther., 10(12):2234-43, 2011.

Scarselli, G.; Rizzello, F.; Cammilli, F.; Ginocchini, L. \& Coccia, M. E. Diagnosis and treatment of endometriosis. A review. Minerva Ginecol., 57(1):55-78, 2005. 
BOHLOULI, S.; KHAZAEI, M.; RABZIA, A.; KHAZAEI, M. R. \& SADEGHI, E. Adiponectin effect on nitric oxide secretion by normal and endometriotic human endometrial stromal cells: in vitro study. Int. J. Morphol., 33(1):337-341, 2015.

Taguchi, M.; Alfer, J.; Chwalisz, K.; Beier, H. M. \& Classen-Linke, I. Endothelial nitric oxide synthase is differently expressed in human endometrial vessels during the menstrual cycle. Mol. Hum. Reprod., 6(2):185-90, 2000.

Takemura, Y.; Osuga, Y.; Harada, M.; Hirata, T.; Koga, K.; Morimoto, C.; Hirota, Y.; Yoshino, O.; Yano, T. \& Taketani, Y. Serum adiponectin concentrations are decreased in women with endometriosis. Hum. Reprod., 20(12):3510-3, 2005.

Takemura, Y.; Osuga, Y.; Yamauchi, T.; Kobayashi, M.; Harada M.; Hirata, T.; Morimoto, C.; Hirota, Y.; Yoshino, O.; Koga, K.; Yano, T.; Kadowaki, T. \& Taketani, Y. Expression of adiponectin receptors and its possible implication in the human endometrium. Endocrinology, 147(7):3203-10, 2006.

Tsikas, D. Analysis of nitrite and nitrate in biological fluids by assays based on the Griess reaction: appraisal of the Griess reaction in the L-arginine/nitric oxide area of research. J. Chromatogr. B Analyt. Technol. Biomed. Life Sci., 851(1-2):51-70, 2007.

Wu, M. Y.; Chao, K. H.; Yang, J. H.; Lee, T. H. Yang, Y. S. \& Ho, H. $\mathrm{N}$. Nitric oxide synthesis is increased in the endometrial tissue of women with endometriosis. Hum. Reprod., 18(12):2668-71, 2003.

Wang, Y.; Lam, K. S.; Yau, M. H. \& Xu, A. Post-translational modifications of adiponectin: mechanisms and functional implications. Biochem. J., 409(3):623-33, 2008.

Yi, K. W.; Shin, J. H.; Park, H. T; Kim, T.; Kim, S. H. \& Hur, J. Y. Resistin concentration is increased in the peritoneal fluid of women with endometriosis. Am. J. Reprod. Immunol., 64(5):31823,2010

\author{
Correspondence to: \\ Ehsan Sadeghi \\ Research Center for Environmental Determinants of Health \\ (RCEDH) \\ Kermanshah University of Medical Sciences \\ Kermanshah \\ IRAN
}

Tel: 00989188365313

Fax: 00988318263048

Email: ehsan_vet@yahoo.com

Received: 21-02-2014

Accepted: 06-12-2014 